\title{
Dividend Payout Ratio and Firm's Profitability. Evidence from Pakistan
}

\author{
Mudassar Hasan', Muhammad Ishfaq Ahmad', Muhammad Yasir Rafiq ${ }^{3}$, \\ Ramiz Ur Rehman 4 \\ ${ }^{1}$ Lahore Business School, The University of Lahore, Lahore, Pakistan \\ ${ }^{2}$ Public Administration and Law School, Liaoning Technical University, Fuxin, China \\ ${ }^{3}$ Government Islamia College of Commerce, Lahore, Pakistan \\ ${ }^{4}$ Lahore Business School, The University of Lahore, Lahore, Pakistan \\ Email: mudassarhasan84@yahoo.com, m ishfaq452@yahoo.com, yasir.stats@gmail.com, \\ ramiz_rehman@hotmail.com
}

Received 5 April 2015; accepted 26 June 2015; published 29 June 2015

Copyright (C) 2015 by authors and Scientific Research Publishing Inc.

This work is licensed under the Creative Commons Attribution International License (CC BY).

http://creativecommons.org/licenses/by/4.0/

(c) (i) Open Access

\begin{abstract}
This paper investigates the relationship between dividend payout ratio and profitability of a firm. For this, two main sectors of Pakistan are selected, energy and textile. The study covers a time span of 1996-2008. Firm performance is measured by earning per share (EPS) and return on assets (ROA). The results of logarithmic regression show that no matter what industry is, there is a negative impact of dividend payout ratio on next year earnings of a firm.
\end{abstract}

\section{Keywords}

Dividend Payout, Earning Per Share, Return on Assets

\section{Introduction}

Corporate earnings are the whole pie which gets split into two parts, the one slice which is distributed to shareholders and the other one which is retained for reinvestment. The parts of earnings which are meant to be distributed to shareholders are known as dividends. Taking the decision about quantity and payment mechanism of the dividends is regarded as dividend policy. Dividend payout ratio is often known as a measure of dividend policy. The most fundamental question is whether or not the dividend should be paid. The corporate finance theory is yet to answer this basic question. That is why dividend policy is considered to be a dark area in corporate finance theory. In corporate finance theory, the bottom line of every decision is to analyze its effect on the 
value of the firm. There could be several answers to this fundamental question but the final picture is still blurred. Dividend policy is itself affected by a number of factors. These factors may be categorized as general and specific. Several studies have shown that dividends follow earnings. We are interested in investigating the other way around: do dividend payout ratios drive profitability?

In perfect markets, finance literature greatly promotes that the dividend policy is irrelevant. Though this argument is often supported by some, most still opine the argument as controversial. Assuming the presence of transactions and taxes, the dividend payout ratio is considered to be a dilemma. Although this argument seems appealing, most companies still tend to pay dividends. Most influential authors of corporate finance theory like Brealey and Myers, Brigham and Gapenski, Van Horne explain the dividend policy in their own way. Where one regards it as one of the " 10 unresolved problems in finance", the other puts it as "one of the most judgmental decisions that a manager must make", and the third believes that the "lack of firm footing for predicting the long-run effect of a specific dividend policy on valuation makes the dividend decision more difficult in many ways than either the investment or financing decisions", respectively.

\section{Review of Literature}

Several researchers have tried shed light on dividend policy. Building on the assumption of perfect markets, [1] took the stand that basic determinants of the firm value happen to be the basic earning power and its business risk. This implies that firm value is unaffected by the decision regarding dividend payout policy so it is irrelevant. [2] argued that increase in dividend payout ratio decreases required return on equity because investors are less certain about capital gains. As capital gains are considered to arise as result of retaining profits and where as dividends are not. So this makes dividends as being less risky than capital gains. In effect, they argued that investors value more to an expected dividend to an expected capital gain as they are less risky. Tax preference theory argued that due to tax benefits are associated with capital gains; capital gains are more valuable to investor than dividends.

Ownership structure and agency problem can also influence dividend policy. After studying shareholder-manager conflict and the proportion of equity held by insiders, [3] illustrated that these two factors should affect dividend payout policy. [4] found different investor groups (clientele) have their own choices about dividends and capital gains which lead a firm to set a dividend payout policy according to the clienteles.

[5] took their stance on signaling hypothesis that dividends contain information asymmetry. This implies shareholders and management have their own set of information which could be quite different from another. Inside information element helps create the difference in a big way. [6] [7] investigated the life cycle effect and market imperfections regarding dividend policy. The studies exhibited that firms should consider their life cycles, significance of market imperfections and how managers assess them primarily in setting up their payout ratios. Additionally, the research also considered several other factors related to the decision of dividend payout ratio including transaction costs, floatation costs, asymmetric information, agency costs and taxes. [8] in their catering theory, suggested that managers tend to cater the needs of the investors. They argued that managers tap the tendency of the investors to set up premiums for stock prices. When investors tend to set stock price high enough to establish a premium, managers tend to pay stable dividends. Alternatively, when investors prefer companies who do not pay dividends, managers are more reluctant to pay dividends.

[9] explored the factors affecting dividend policy. These factors include periodic variation of investment opportunities, profitability, and the prospects for growth for industry and for the firm. Another explanation provided by [10] showed a relationship between dividend payout policy, profitability volatility, and investment needs. This relationship was explored while studying the capital structure decisions. Meanwhile, [11]-[13] conducted studies over American companies which also added value to their stance. Studies have shown that, undoubtedly, dividend payout policy depends upon company specific factors. It was [14] who claimed that the decision is also affected by industry-wide variable. As [15] [16] established every industry has its own distinct dividend payout policy. However, whether paying out dividends have a feedback effect on earnings or not, are the question which still needs to answer? Our study aims to investigate the very fact.

\section{Methodology}

The study explores the relationship between dividend payout ratio and firm's earnings. It compares two different 
sectors of Pakistani industry in this respect, one with high dividend payout ratio (DPRES) i.e., Fuel and Energy Sector and other with low (mostly zero) dividend payout ratio (DPRTS) i.e., Textile Sector. The other variables are earning per shares (ESPES, EPSTS), return on assets (ROAES, ROATS) and t represents years. The analysis covers a period of twelve years i.e. 1996-2008. All variables cover a period of eleven years but differing in terms of starting and ending points i.e. DPR (1996-2007) and both ROA and EPS (1997-2008). The reason of choosing this particular era is the variation of economic indicators in Pakistan. We have experienced a high economic growth in that decade and afterward a sharp decline too. No previous study is available on this particular aspect, especially in Pakistan. This can be done by applying the following econometric models.

$$
\begin{aligned}
& \operatorname{LogEPS}_{\mathrm{ES}(\mathrm{t}+1)}=\alpha_{1}+\beta_{1} \operatorname{LogDPR}_{\mathrm{ES}(\mathrm{t})}+\epsilon_{1} \\
& \log \mathrm{ROA}_{\mathrm{ES}(\mathrm{t}+1)}=\alpha_{2}+\beta_{2} \log \mathrm{DPR}_{\mathrm{ES}(\mathrm{t})}+\epsilon_{2} \\
& \log \mathrm{EPS}_{\mathrm{TS}(\mathrm{t}+1)}=\alpha_{2}+\beta_{2} \log \mathrm{DPR}_{\mathrm{TS}(\mathrm{t})}+\epsilon_{3} \\
& \log \mathrm{ROA}_{\mathrm{TS}(\mathrm{t}+1)}=\alpha_{2}+\beta_{2} \operatorname{LogDPR}_{\mathrm{TS}(\mathrm{t})}+\epsilon_{4}
\end{aligned}
$$

\section{Expected Signs}

The expected signs are as follows: $\beta_{1}<0, \beta_{2}<0, \beta_{3}<0$, and $\beta_{4}<0, \epsilon_{i}$ is the error term, where $i=1,2,3, \cdots$. $\epsilon_{i}-N\left(0, \sigma^{2}\right)$. There is no multi-co-linearity problem in model 3 . All the models follow the assumptions of classical linear regression model. The significance of these models will be further analyzed by applying ANOVA (Analysis of Variance). The coefficients of independent variables (Dividend Payout Ratios) for model 1 and 2 will also be compared for energy and textile sector.

\section{Result and Discussion}

The analysis is conducted in two steps, firstly, descriptive statistics of all the variables are evaluated, and secondly, the logarithmic regression is applied on four models. The results show that there is a mixed trend in setting up the dividend policy of both sectors. There is inconsistency in the dividend payout ratio during the last eleven years. Same trend is observed for the profitability of both sectors. But Energy sector is quite consistent with its profitability as compared to textile sector.

In energy sector, the mean return on asset is $28.52 \%$ where as its standard deviation is $96.28 \%$. These statistics are clear evidence of inconsistency in profitability, but when we compare this with textile sector standard deviation of return on asset is $200.53 \%$, then it seems to be low. The mean dividend payout ratio in energy sector is $37 \%$ whereas in textile sector it is only $12 \%$. In both sector the standard deviation of dividend payout ratio is quite high, which shows the inconsistency in dividend policy (see Table 1).

The study aims at exploring the affect of dividend policy on profitability of a firm, specifically considering industry characteristics. For this, four different models are set up and log regression is applied to determine the lag impact of dividend policy on the return on asset and earnings per share of energy and textile sectors. In model 1 , $\mathrm{R}$ square is $57 \%$ which shows strength of the model. The negative beta coefficient shows the negative impact of dividend payout ratio on the earning per share. The $\mathrm{p}$ value shows that, at 5 percent level of significant, the model is significant. The Durban Watson value shows that there is no auto correlation between independent and dependent variable. In model 2 , beta coefficient is -0.31 , which shows a negative impact of dividend payout ratio on return on asset, whereas, p-value is 0.00 which highly significant at $5 \%$ level of significance. In model 3 , $\mathrm{R}$ square is comparatively low at $42 \%$ but still it is on a higher node. This model has also a negative beta coefficient and a very high significant p-value. Similarly, in model 4, beta coefficient is also negative with significant p-value (see Table 2).

\section{Conclusion}

This paper tries to cover some ignored areas in the theory. The dividend policy is always a very hot topic for academicians. Many papers have been written on this subject, but no one studied the lag effect of dividend payout ratio on profitability of a firm. In this paper, we covered two big sectors of Pakistan, energy and textile. The results show that there is a negative impact of dividend payout ratio on the profitability of a firm. These results 
Table 1. (a) Descriptive statistics (energy sector); (b) Descriptive statistics (textile sector).

(a)

\begin{tabular}{ccccc}
\hline & No of Observations & Mean & Std. Dev & Std. Error \\
\hline ROA & 283 & $38.15 \%$ & 83.34 & 7.01 \\
EPS & 283 & 17.12 & 21.17 & 1.32 \\
DPR & 283 & $32.19 \%$ & 0.70 & 0.04 \\
\hline
\end{tabular}

Note: EPS is in Pak rupees.

(b)

\begin{tabular}{ccccc}
\hline & No of Observations & Mean & Std. Dev & Std. Error \\
\hline ROA & 1932 & $38.76 \%$ & 167.13 & 5.74 \\
EPS & 1932 & 4.76 & 14.97 & 0.33 \\
DPR & 1932 & $16.00 \%$ & 0.56 & 0.02 \\
\hline
\end{tabular}

Note: EPS is in Pak rupees.

Table 2. Regression results of the studied model.

\begin{tabular}{ccccccc}
\hline Model & R Sq & A & $\beta$ & t-stat & p-value & DW \\
\hline 1 & 0.57 & 0.396 & -0.45 & $11.08<\mathrm{t}>-8.24$ & $0.01^{*}$ & 1.54 \\
2 & 0.55 & 0.347 & -0.31 & $8.52<\mathrm{t}>-5.23$ & $0.00^{*}$ & 0.96 \\
3 & 0.42 & 0.579 & -0.19 & $12.67<\mathrm{t}>-9$ & $0.03^{*}$ & 1.18 \\
4 & 0.62 & 0.514 & -0.52 & $18.75<\mathrm{t}>-14.26$ & $0.02^{*}$ & 1.67 \\
\hline
\end{tabular}

*Significance at alpha $5 \%$.

are very surprising and giving new dimensions to the finance researchers to further study in this area and find out the insights.

\section{References}

[1] Miller, M. and Modigliani, F. (1961) Dividend Policy, Growth and the Valuation of Shares. Journal of Business, 34, 411-433. http://dx.doi.org/10.1086/294442

[2] Gordon, M.J. (1963) Optimal Investment and Financing Policy. Journal of Finance, 18, $264-272$.

[3] Jensen, M.C. and Meckling, W.H. (1976) Theory of the Firms: Managerial Behavior, Agency Costs and Ownership Structure. Journal of Financial Economics, 3, 305-360. http://dx.doi.org/10.1016/0304-405X(76)90026-X

[4] Miller, M. and Scholes, M. (1978) Dividends and Taxes. Journal of Financial Economics, 6, 333-364. http://dx.doi.org/10.1016/0304-405X(78)90009-0

[5] Bhattacharya, S. (1979) Imperfect Information, Dividend Policy and the Bird in the Hand Fallacy. Bell Journal of Economics, 10, 259-270. http://dx.doi.org/10.2307/3003330

[6] Lease, R.C., John, K., Kalay, A., Loewenstein, U. and Sarig, O.D. (2000) Dividend Policy: Its Impact on Firm Value. Harvard Business School Press, Boston.

[7] Fama, E.F. and French, K.R. (2001) Disappearing Dividends: Changing Firm Characteristics or Lower Propensity to Pay? Journal of Financial Economics, 60, 3-43. http://dx.doi.org/10.1016/S0304-405X(01)00038-1

[8] Baker, M. and Wurgler, J. (2004) A Catering Theory of Dividends. Journal of Finance, 59, 1125-1165. http://dx.doi.org/10.1111/j.1540-6261.2004.00658.x

[9] Lintner, J. (1956) Distribution of Incomes of Corporations among Dividends, Retained Earnings, and Taxes. American Economic Review, 46, 97-113.

[10] Myers, S.C. (1984) The Capital Structure Puzzle. Journal of Finance, 39, 575-592. http://dx.doi.org/10.2307/2327916

[11] Jensen, G., Solberg, D. and Zorn, T. (1992) Simultaneous Determination of Insider Ownership, Debt, and Dividend Policies. Journal of Financial and Quantitative Analysis, 27, 247-263. http://dx.doi.org/10.2307/2331370

[12] McCabe, G.M. (1979) The Empirical Relationship between Investment and Financing: A New Look. Journal of Fi- 
nancial and Quantitative Analysis, 14, 119-135. http://dx.doi.org/10.2307/2330658

[13] Rozeff, M. (1982) Growth, Beta and Agency Costs as Determinants of Dividend Payout Ratios. Journal of Financial Research, 5, 249-259. http://dx.doi.org/10.1111/j.1475-6803.1982.tb00299.x

[14] Lintner, J. (1953) The Determinants of Corporate Savings. In: Boddy, F. and Nelson, C., Eds., Savings in the Modern Economy, University of Minnesota Press, Minneapolis.

[15] Baker, H.K. (1988) The Relationship between Industry Classification and Dividend Policy. Southern Business Review, 14, 1-8.

[16] Michel, A. (1979) Industry Influence on Dividend Policy. Financial Management, 8, 22-26. http://dx.doi.org/10.2307/3665034 